\title{
Life cycle and performance among SMEs: Swedish empirical evidence
}

\author{
Darush Yazdanfar and Peter Öhman \\ Department of Business, Economics and Law, Mid Sweden University, \\ Sundsvall, Sweden
}

\section{Life cycle and performance among SMEs}

Received 7 April 2014 Revised 30 May 2014 Accepted 10 June 2014

\begin{abstract}
Purpose - This study aims to empirically examine the applicability of the life cycle model of firm performance to growth and profitability among Swedish small- and medium-sized enterprises (SMEs). Design/methodology/approach - Using analysis of variance, multiple analysis of variance and three-stage least square modelling, this study analyses a longitudinal data set covering 26,721 Swedish SMEs in six industries from 2008 to 2011.

Findings - The empirical results indicate a clear life cycle performance pattern among the sampled SMEs, and that a six-stage life cycle model is applicable in predicting the performance pattern in terms of growth and profitability. On average, younger SMEs tend to display better performance in terms of growth and profitability than do their older and larger counterparts; moreover, larger SMEs tend to achieve better performance than do smaller ones.

Practical implications - The findings help SME managers understand how their decision-making style, strategy and structure can be related to various life cycle stages. Such an understanding may help them improve firm performance over time. Policymakers may find the results useful in coordinating SME support in line with various life cycle stages.

Originality/value - To the authors' knowledge, this study is one of only a few using two performance variables to test the applicability of the life cycle model in a longitudinal and cross-industrial sample.
\end{abstract}

Keywords Sweden, SMEs, Life cycle stages, Performance path

Paper type Research paper

\section{Introduction}

The firm life cycle model has attracted considerable attention in recent decades as a conceptual framework for understanding and analysing various aspects of firm development in the management literature (Aghion et al., 2007). By applying the model, empirical research has explored various topics, including financial performance (Anthony and Ramesh, 1992), growth (Klepper, 1996; Fitzsimmons et al., 2005), profitability and cash flow (Dickinson, 2011), firm financing (Berger and Udell, 1998; Fama and French, 2000), entrepreneurship (Quinn and Cameron, 1983) and strategy (Lester et al., 2003, 2006). The model has provided a useful theoretical framework for researchers and practitioners. From the managerial perspective, the putative power of the life cycle model can help managers predict potential problems and opportunities in various life stages. However, since firms may operate in multiple industries and produce different types of products and services, a firm's life cycle stages are difficult to identify precisely. This may explain why empirical research into the relationship between firm performance and life cycle stage is rather rare.

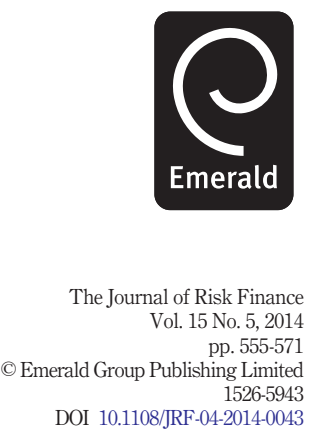


$\mathrm{JRF}$

15,5

556

The purpose of this study is to empirically examine the applicability of the life cycle model to the firm performance path in a sample of Swedish SMEs across six industries from 2008 to 2011. The main contribution is the provision of evidence regarding the applicability of the life cycle model to SME performance in Sweden. To the author's knowledge, this is one of only a few studies to consider the relationship between life cycle stage and performance in SMEs using two proxy variables for performance: growth and profitability. Given that the performance life cycle concept is important in SME strategic planning, these practical contributions might help managers and policymakers aiming to improve SME performance.

The remainder of this paper is organized as follows. Section 2 treats the theoretical framework and literature related to the topic. Section 3 outlines the variables, sample, data and statistical techniques used, while the empirical results are reported in Section 4. Section 5 concludes the paper.

\section{Theoretical framework, previous studies, and hypotheses}

According to the life cycle model, a firm - like any living organism - develops through various stages. Consequently, the life cycle of a firm typically consists of a set of stages that starts with birth and ends in death. A life cycle stage can be described as a phase of firm organizational operations and structures. According to Hanks et al. (1993), a life cycle stage is a "unique configuration of variables related to organization, context and structure". Common contextual dimensions include age, size, growth and profitability rate. The advantage of applying a life cycle approach is that it emphasizes that activity and structure change over time. The number, nature, length and breadth of life cycle stages have been interpreted and implemented in various ways. While Quinn and Cameron (1983) and Kazanjian and Drazin (1989) identified four stages in the business life cycle process, Scott and Bruce (1987) and Hanks et al. (1993) identified a five-stage model. Furthermore, Tam et al. (2001) recommend a six-stage and Adizes (1989) a ten-stage model.

The basic assumption of all these interpretations is that every stage of a firm's life cycle is associated with particular challenges and opportunities. Theoretically, certain aspects of firms, including performance in terms of growth and profitability, are associated with these stages, following an inverted U-shape over time: increasing initially and declining with age. Accordingly, as firms progress through the life cycle, they tend to change or adapt their management styles, organization structures, communication and decision-making processes, reward systems and strategies. This change, or adaptation, is a vital requirement for efficient resource use and for survival.

As demonstrated above, there is no consensus regarding the number of firm life cycle stages: most models have up to five stages, while the remaining models have six to ten. Moreover, the applicability of life cycle models has, like other theoretical models, been criticized for various reasons, some more fundamental than others. The criticisms can be classified into five categories: empirical applicability and validation (Levie and Lichtenstein, 2010); the nature of life cycle models, i.e. focusing on symptoms and not explanations; life cycle models chart one-way development, regression being ignored (O'Farrell and Hitchens, 1988); the models describe a linear pathway (Lester et al., 2003); and the models usually measure firm size in terms of sales or number of employees, usually ignoring other measures of achievement or performance such as value added (O’Farrell and Hitchens, 1988). 
According to previous research, young SMEs tend to experience high growth (Evans, 1987; Mead and Liedholm, 1998, Lester et al., 2006; Barba Navaretti et al., 2014), high and volatile profitability (Dunlop, 1992) and high risk (James and Wier, 1990; Berger and Udell, 1998). They are also likely less diversified than older firms (Campa and Kedia, 2002). Various theoretical frameworks have been developed to explain the relationship between life cycle stage and performance. James and Wier (1990) and Berger and Udell (1998) implement risk/return approaches, suggesting that as a firm ages, bankruptcy risk declines over life stages, so the required rates of return decrease.

Based on the entrepreneurial activity approach, markets undergo continuous change, creating profit opportunities for firms that are able and ready to act (Kirzner, 1997). As firms age they likely lose their entrepreneurial ability to meet changing market requirements and thereby to exploit growth and profit opportunities (Sorensen and Stuart, 2000). Likewise, in line with the organizational approach, age can influence performance by inducing organizational inertia, suggesting an inverted U-shaped relationship between firm age and performance (Leonard-Barton, 1992). However, previous empirical research disagrees as to the relationship between firm age and performance. Several previous studies have suggested a negative relationship (Leonard-Barton, 1992; Fairfield et al., 1996; Fama and French, 2000; Nissim and Penman, 2001; Geroski and Gugler, 2004; Lotti et al., 2009; Barba Navaretti et al., 2014). However, Das (1995) and Shanmugam and Bhaduri (2002) found a positive relationship between age and performance in terms of growth. Maçãs Nunes et al. (2012) proposed a positive relationship between age and performance in terms of profitability among young SMEs, and a negative and significant such relationship among old SMEs. Majumdar (1997) found evidence indicating that older Indian firms tend to be more productive but less profitable than young ones, while Fariñas and Moreno (2000) suggested no significant relationship between age and growth. The ambiguous relationship between firm life cycle and performance suggested by Jovanovic (1982) is supported by studies from Belgium (Maes et al., 2005), Portugal (Serrasquiero et al., 2010) and Spain (Coad et al., 2013).

According to the life cycle perspective, a firm's performance is high during the start-up stage and gradually decreases as the firm ages. Hence, the fundamental assumption of this study is that, given the life cycle model, as firms age, it is theoretically likely that their performance will decline. The expectation is that firm performance differs between life cycle stages, declining as firms age (Fama and French, 2000; Almeida and Campello, 2007; Hobdari et al., 2009). In line with this theoretical framework and previous studies, the following hypothesis is formulated:

H1. Life cycle stage and performance are negatively related in terms of growth and profitability.

In addition, firms tend to be small in the start-up stage, when they are simply organized with few employees and limited market shares. As they develop through the life cycle stages, firms increase in size (Galbraith and Nathanson, 1979; Lester et al., 2006; Serrasquiero et al., 2010; Coad et al., 2013). An additional hypothesis is formulated to test size as a control variable, as follows:

H2. Life cycle stage and firm size are positively related in terms of sales.

\section{Life cycle and performance among SMEs}


JRF

15,5

558

Firm size is assumed to be a determinant of performance (Storey, 1994; Beck et al., 2005), but the nature of the relationship between firm size and performance has been the subject of disagreement. Gschwandtner (2005), Almeida and Campello (2007) and Asimakopoulos et al. (2009) have found that smaller firms are more likely to display high performance than are larger firms. However, several previous studies suggest that smaller firms face various challenges, such as financial constraints, that negatively affect their performance (Yasuda, 2005; Oliveira and Fortunato, 2006), indicating a positive relationship between firm size and performance (Goddard et al., 2005; Reichstein et al., 2010; Stierwald, 2010).

Due to the lack of consensus as to whether firm size has a general effect on performance, the second additional hypothesis, which entails testing size as a control variable, is based on the hypothesised relationship between life cycle stage and firm size. The third hypothesis is formulated as follows:

H3. Firm size and performance are negatively related in terms of growth and profitability.

\section{Selection of variables, data collection and data analyses}

\subsection{Selection of variables}

The dependent variable in this study is performance, which can be defined and measured in various ways, for example, in terms of number of employees, market share, turnover, value-added, sales and profitability (Rajan and Zingales, 1995). Unlike most previous studies, the present study uses two measures, growth and profitability, as proxies for firm performance. This choice may improve the robustness of the study, and thereby increase the validity of the results.

In line with previous studies (Hart, 2000; Beck et al., 2005; Fitzsimmons et al., 2005), firm growth was measured as the percentage change in sales over a year. Profitability was defined as the book value of net profit after tax divided by total assets, i.e. return on assets (Jovanovic, 1982; Fairfield et al., 1996; Fama and French, 2000).

Based on the argument presented by Tam et al. (2001), the present study examines the applicability of the six-stage life cycle model. The SMEs in the sample were classified by age into six categories in five-year intervals ranging from 1 to 25 years, with a single category for firms older than 25 years. Accordingly, the age category was used as a proxy for life cycle. Firm age has generally been regarded as a proxy for life cycle stage, and as one of the most important independent variables affecting firm performance (Storey, 1994). Since this study focuses on two dependent variables, growth and profitability, which are both related to firm sales, the natural logarithm of firm sales has been used as a proxy for firm size.

\subsection{Sample, data collection and data analyses}

To test the hypotheses, comprehensive data sets were obtained from Affärsdata, a commercial database that provides detailed accounting data covering all registered limited liability companies in Sweden. The sample includes all Swedish SMEs in six industries from 2008 to 2011. According to Statistics Sweden (2011), SMEs are defined as firms with fewer than 200 employees. Panel data based on financial statements usually suffer from outliers or missing data. To solve this problem, all SMEs for which there were any negative values or outliers were excluded from the data. To minimize the risk of sample selection bias, firms involved in a bankruptcy process, with annual 
operating revenue less than SEK 120,000 (EUR 13,400) or total assets less than SEK 100,000 (EUR 11,200), and without employees were excluded from the data set. Subsequently, a total of 26,721 SMEs in six industries (i.e. the metal, transport, retail trade, consulting, restaurant and construction industries) were included in the final sample (firms were classified using a one-digit standard industrial classification code). The following section summarizes the descriptive statistics for the sample.

Several statistical techniques, i.e. analysis of variance (ANOVA), multiple analysis of variance (MANOVA) and three-stage least square (3SLS) modelling, were used to test the hypotheses. Since the main independent variable, life cycle stage, is a categorical variable, ANOVA was employed to assess whether firm performance and size differed significantly over the life cycle stages of the sampled firms. MANOVA was used to construct a multiple comparison of multivariate data. A combination of the variables life cycle stage, growth, profitability and size was therefore included in the MANOVA model. To evaluate the results of ANOVA and MANOVA, and to avoid potential endogeneity, additional tests were performed using the 3SLS model. This model combines two-stage least squares regression and multivariate seemingly unrelated regression estimation to deal with the covariances across equation disturbances (Zellner and Theil, 1962). The underlying equation in the 3SLS model is as follows:

$$
\begin{aligned}
& Y_{1}=\alpha_{0}+\beta_{1}\left(X_{1}\right)+\beta_{2}\left(X_{2}\right)+\varepsilon \\
& Y_{2}=\alpha_{0}+\beta_{1}\left(X_{1}\right)+\beta_{2}\left(X_{2}\right)+\varepsilon
\end{aligned}
$$

where

$$
\begin{aligned}
& Y_{1}=\text { growth } \\
& Y_{2}=\text { profitability. } \\
& \alpha_{0}=\text { constant } \\
& X_{1}=\text { life cycle stage. } \\
& X_{2}=\text { size. } \\
& \varepsilon=\text { an error term. }
\end{aligned}
$$

\section{Empirical results}

\subsection{Descriptive statistics}

Table I summarizes the descriptive statistics. Over 40 per cent of the firms operate in the consulting industry, though the retail trade industry is also significantly represented. The firms in the sample, on average, have seven employees each and are 17 years old. As indicated by the descriptive statistics, the sample is characterized by homogeneity among the industries in terms of number of employees, age and size (measured as the natural logarithm of sales). However, the rates of both performance proxies, growth and profitability, vary considerably among industries, averaging approximately 9 per cent (standard deviation, 41 per cent) and 15 per cent (standard deviation, 19 per cent), respectively. The consulting industry has the highest performance rates in terms of both growth (13 per cent) and profitability (21 per cent), while the transport, retail trade and construction industries have relatively low performance rates for growth as well as

\section{Life cycle and performance among SMEs}


JRF

560

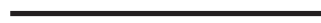

Table I.

Descriptive statistics of sample firms (means and standard deviations of variables, and total)

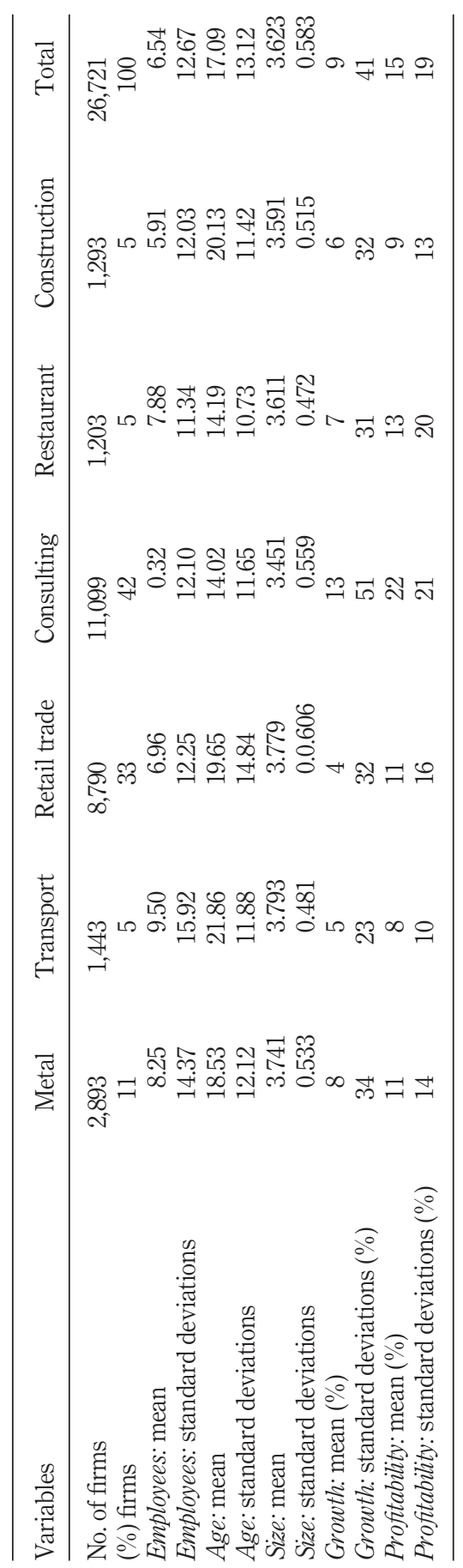


profitability. The high standard deviations indicate considerable variation in firm performance within all six industries investigated.

\subsection{Correlation analysis}

The correlation matrix of the dependent and independent variables is presented in Table II. We examined the direction and significance of the relationships among the variables included in the model and the possible degree of collinearity among them. A negative and significant correlation is observed between life cycle stage and performance in terms of growth and profitability, implying that younger firms on average tend to be characterized by better performance. Growth and profitability are significantly and positively related to each other $(r=0.255, p=0.000)$. Table II further shows that there is a positive and significant relationship between life cycle stage and size, indicating that firm size increases with age. Moreover, significantly positive correlations are observed between firm size, on one hand, and growth and profitability, respectively, on the other. As can be observed, the correlation coefficients are not large enough to cause collinearity problems in the regressions, and are statistically significant at the usual levels of significance.

\subsection{Results of ANOVA}

4.3.1 Growth. The descriptive results presented in Table II indicate that the firms are relatively evenly distributed between life cycle stages. Table III further indicates that very young firms (age $\leq 5$ years) grow on average more than do firms in the other age categories. The growth rate is 21 per cent for the youngest age category firms, decreasing gradually over the life cycle to 4 per cent for the oldest age category firms. The results of the ANOVA indicate significant differences in growth across different life cycle stages at the 5 per cent level $(\mathrm{F}=358.02, p=0.000)$. Consistent with $H 1$, the findings confirm that, as firms age, their growth rates systematically decline through the life cycle. Moreover, as reported in Table II, a negative and significant correlation $(r=-0.110, p=0.000)$ is observed between a firm's life cycle stage and its growth, reconfirming that older firms are characterized by lower growth.

To examine the validity of the results, several tests, including Welch's $(p=0.000)$ and Levene's $(p=0.000) t$-statistics, Wilks' lambda $(p=0.000)$, Lawley-Hotelling trace

\begin{tabular}{lcccc}
\hline Variables & Life cycle stage & Growth & Profitability & Size \\
\hline Life cycle stage & 1 & $-0.110^{* *}$ & $-0.196^{* *}$ & $0.165^{* *}$ \\
& & 0.000 & 0.000 & 0.000 \\
Growth & $-0.110^{* * *}$ & 1 & $0.255^{* *}$ & $0.054^{* *}$ \\
& 0.000 & & 0.000 & 0.000 \\
Profitability & $-0.196^{* *}$ & $0.255^{* *}$ & 1 & $0.022^{* *}$ \\
Size & 0.000 & 0.000 & & 0 \\
& $0.165^{* *}$ & $0.054^{* *}$ & $0.022^{* *}$ & 1 \\
$n$ (firms) & 0.000 & 0.000 & 0.000 & \\
$n$ observations (four years) & 106,821 & 26,721 & 26,721 & 26,721 \\
& & 106,884 & 106,884 & 106,884
\end{tabular}

Notes: **, *Correlations are significant at the 0.01 and 0.05 levels, respectively (two-tailed)

\section{Life cycle and performance among SMEs}

561

\section{(1)}


JRF
15,5

562
Table III.

ANOVA of the growth rate through the firm's life cycle stages

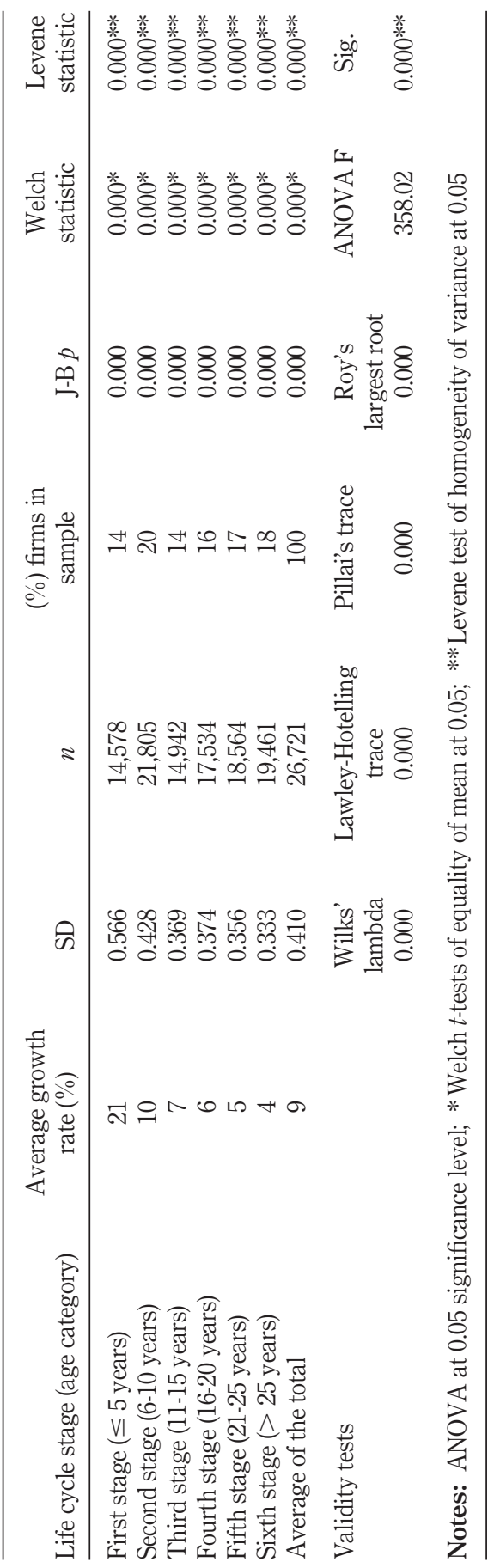




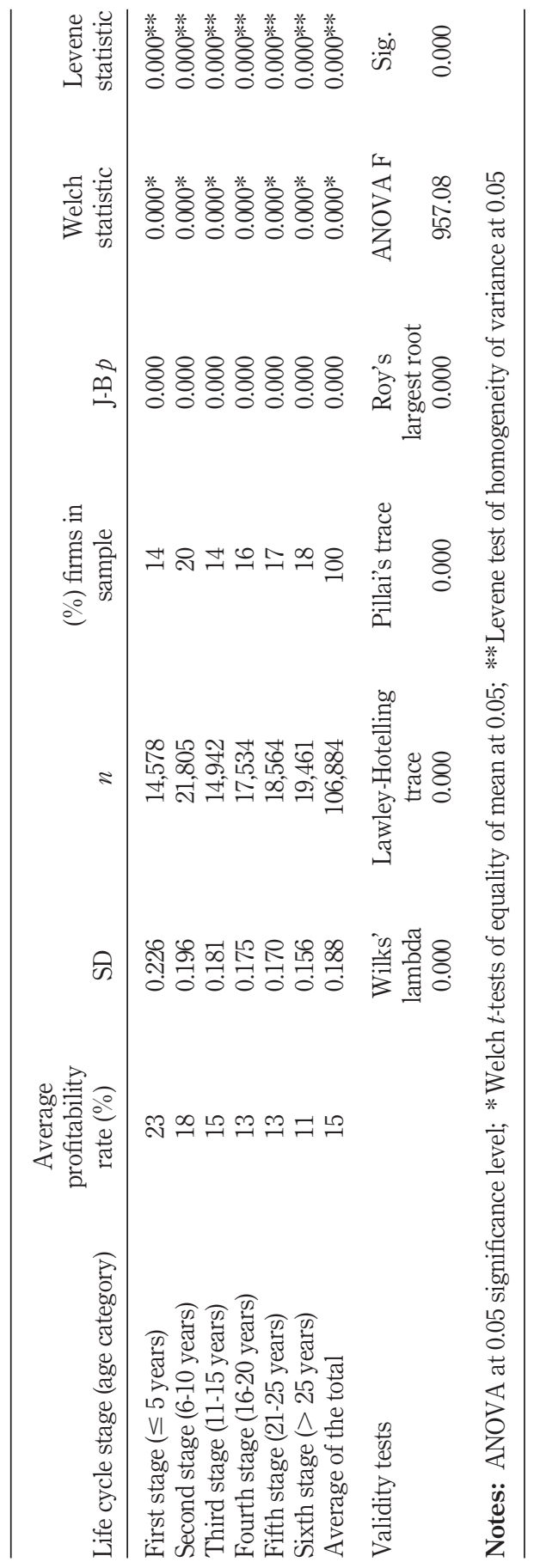

\section{Life cycle and performance among SMEs}

563

Table IV. ANOVA of the profitability rate through the firm's life cycle stages 
$\mathrm{JRF}$

15,5

564

$(p=0.000)$, Pillai's trace $(p=0.000)$ and Roy's largest root $(p=0.000)$ were performed. All these tests demonstrate the robustness of the results.

4.3.2 Profitability. As shown in Table IV, the mean profitability is high in the first stage of the firm's life cycle (23 per cent), decreasing gradually to 11 per cent in the sixth stage. Thus, in agreement with $H 1$, the results provide evidence that profitability rates vary significantly at the 5 per cent level across all life cycle stages $(F=957.08, p=$ 0.000 ), supporting the existence of a life cycle effect on profitability. The correlation sign in Table II $(r=-0.196, p=0.000)$ also indicates a significant and inverse relationship between life cycle stage and profitability.

Several diagnostic tests, including Welch's $(\phi=0.000)$ and Levene's $(\phi=0.000)$ $t$-statistics, which examine variable equality and the homogeneity of variance of the population, were conducted, confirming the reliability of the results. Moreover, the corresponding values of Wilks' lambda, Lawley-Hotelling trace, Pillai's trace and Roy's largest root indicated the robustness of the results, meaning that life cycle stage indeed influences profitability.

4.3.3 Size. To investigate the relationship between size and life cycle stage, an ANOVA was conducted. Table $\mathrm{V}$ shows that the mean firm size is relatively small in the first stage of the firm's life cycle, increasing steadily through the various stages. The sign of the correlation coefficient in Table II $(r=0.165, p=0.000)$ also confirms a positive and significant relationship between firm size and life cycle stage, indicating that firm size increases gradually with life cycle stage. Hence, $H 2$, which states that a firm's size is positively related to its life cycle stage, is supported.

Welch's $(p=0.000)$ and Levene's $(p=0.000) t$-statistics confirm the reliability of the results. Additional diagnostic analyses of the results, including Wilks' lambda, Lawley-Hotelling trace, Pillai's trace and Roy's greatest root, confirm the validity of the results.

\subsection{Results of MANOVA}

A MANOVA model without interactions was constructed to assess how performance in terms of growth and profitability is influenced jointly by life cycle stage and size. Table VI presents the MANOVA results for the impact of life cycle stage and size on performance. Both life cycle stage and size are found to exert a significant effect on growth $(F=1,576.937, p=0.000 ; F=4,549.646, p=0.000)$ and on profitability $(F=$ $582.455, p=0.000 ; F=336.390, p=0.000)$. Accordingly, younger and larger SMEs are more likely to have better performance than are older and smaller firms. Furthermore, additional diagnostic analyses confirm that life cycle stage and the control variable size are related to performance separately. These findings support H1. However, in Table II, the signs of the correlations between size and growth $(r=0.054, p=0.000)$ and between size and profitability $(r=0.022, p=0.000)$ confirm a positive relationship between firm size and performance, which is in contrast to $H 3$.

The results of the 3SLS model reported in Table VII further confirm that life cycle stage and size are significantly related to growth and profitability. The relationships between life cycle stage and the two performance proxies are negative, while positive relationships are observed between size and the performance proxies. The results of 3SLS model analyses support the findings of the ANOVA and MANOVA tests presented previously. 


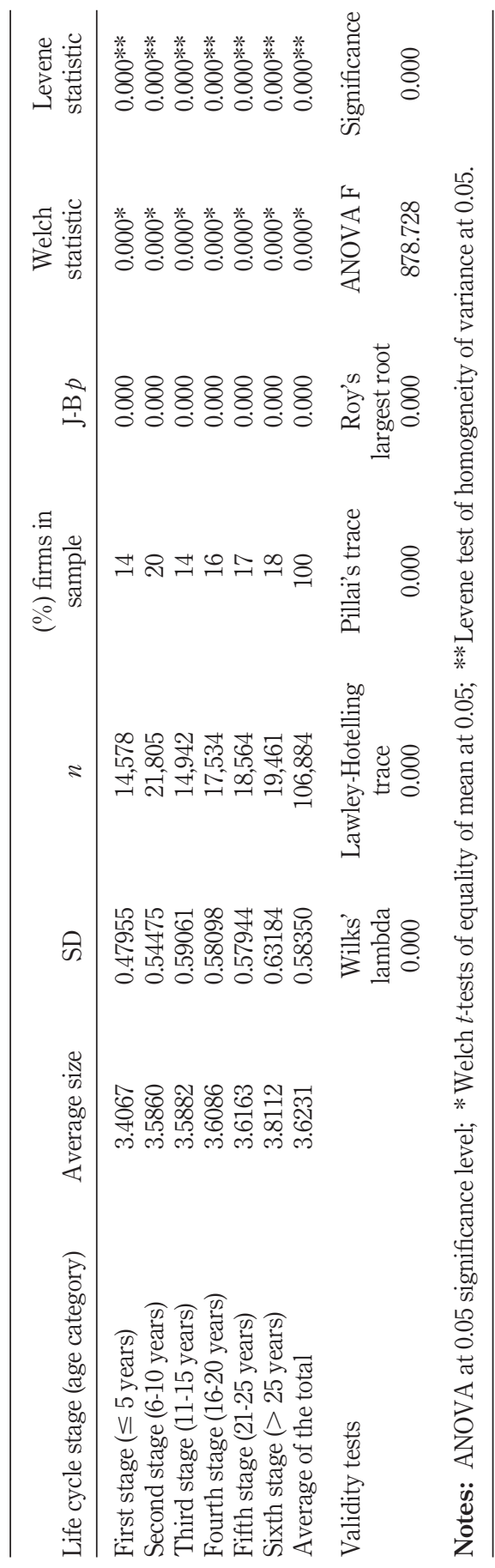

Life cycle and performance among SMEs

565

Table V. ANOVA of firm size through the firm's life cycle stages 
$\mathrm{JRF}$

15,5

566

Table VI.

Results of MANOVA of the relationship between life cycle stage, firm size, and performance in terms of growth and profitability
Overall, the results indicate that the sampled firms can be grouped into life cycle stages based on performance level measured by growth and profitability rates. Consistent with $H 1$, the results provide evidence that younger firms have higher average performance in terms of growth and profitability. The present results thereby extend previous research into the life cycle model (Fairfield et al., 1996; Fama and French, 2000; Nissim and Penman, 2001; Almeida and Campello, 2007; Hobdari et al., 2009; Lotti et al., 2009; Serrasquiero et al., 2010; Barba Navaretti et al., 2014). The positive relationship between life cycle stage and firm size is in line with $H 2$ and supported by the findings of previous research (Serrasquiero et al., 2010; Coad et al., 2013). Larger SMEs are more likely to be high-performance firms than are their smaller counterparts, which is in contrast to $H 3$ but in agreement with several previous studies (Goddard et al., 2005; Yasuda, 2005; Oliveira and Fortunato, 2006; Reichstein et al., 2010; Stierwald, 2010).

\section{Concluding discussion}

The high performance of SMEs is a precondition for their survival and thereby job creation. Although the life cycle approach has been applied to explain several aspects of the firm (Berger and Udell, 1998; Lester et al., 2003; Fitzsimmons et al., 2005; Aghion et al., 2007; Dickinson, 2011), empirical studies of its applicability to reliable performance measures are limited. In line with the life cycle model, the present study examined the impact of life cycle on performance among Swedish SMEs in six industries using a large panel data set covering 26,721 firms from 2008 to 2011. The empirical results indicate a clear life cycle performance pattern among the studied SMEs. The results indicate that performance in terms of growth and profitability is, on average, considerably higher in young SMEs than in their older counterparts. Thus, firm performance follows a pattern explainable by firm life cycle stage (Fama and French, 2000; Hobdari et al., 2009 Lotti et al., 2009; Serrasquiero et al., 2010). The present study contributes to the literature by drawing a more detailed picture of the relationship between life cycle stages and the performance path by measuring performance in terms of both growth and profitability.

The pattern of the relationship between firm life cycle stage and performance should be a priority for owners, managers and policymakers. Firms develop through several life cycle stages, each entailing certain problems and opportunities. Effective resource use and firm survival require that owners and managers adapt appropriate strategies and management styles to each life cycle stage. For example, growth is a primary goal of many firms in the early life cycle stages (Lester et al., 2006), when such a focus is preferably accompanied by a focus on profitability. For less profitable firms in later life

\begin{tabular}{lccccc}
\hline Source & Sum of squares & df & Mean square & $F$ & Significance \\
\hline $\begin{array}{l}\text { Life cycle stage } \\
\text { Growth }\end{array}$ & 260.6055 & 1 & 260.6055 & 1576.937 & $0.000^{*}$ \\
$\begin{array}{l}\text { Profitability } \\
\text { Size }\end{array}$ & 154.382 & 1 & 154.382 & 4549.646 & $0.000^{*}$ \\
Growth & 96.2569 & 1 & 96.2569 & 582.455 & $0.000^{*}$ \\
Profitability & 11.41465 & 1 & 11.41465 & 336.390 & $0.000^{*}$ \\
Note: * Significance level of 0.05. & & & & \\
\end{tabular}




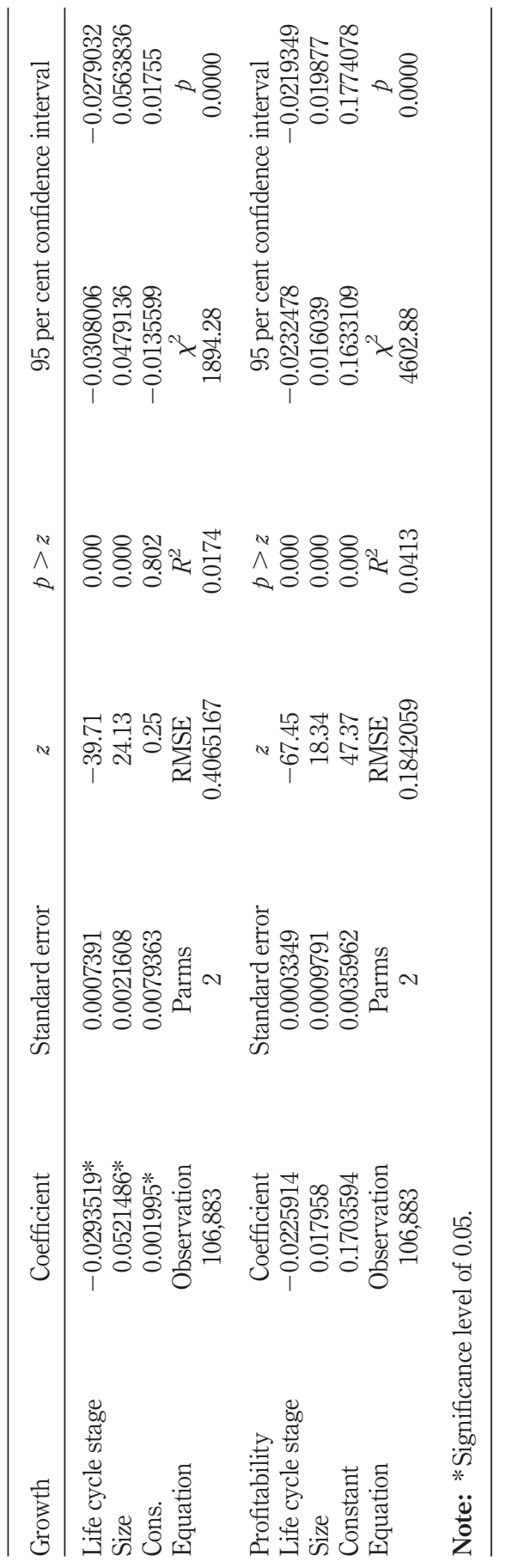

\section{Life cycle and performance among SMEs}

Table VII. Summary of 3SLS model of the relationship between life cycle stage and size, and growth and profitability, respectively 
JRF

15,5

568

cycle stages, Lester et al. (2006) suggest a focus on innovative activities and customer-perceived values rather than on low costs. In addition, by moving into new markets and/or developing new products for existing customers, older SMEs can renew themselves and possibly initiate a new life cycle. For larger firms, outsourcing can be an alternative for inducing viability-enhancing change. For smaller firms struggling to be profitable in their usual businesses, mergers can be an alternative.

While researchers may find the life cycle model a useful analytical tool, policymakers can use the results to coordinate support to SMEs that display dynamic opportunities for business success. This suggestion is in line with that of Maçãs Nunes et al. (2012), who proposed governmental support for young SMEs through the creation of special long-term lines of credit. Such initiatives may allow young SMEs to take advantage of good investment opportunities in the early life cycle stages without creating stress in managing financial resources.

This study is, admittedly, subject to limitations. The applicability of the life cycle model to performance is based on the comparison of means, providing average performance across six age categories. Such modelling provides a picture of reality neglecting the dissimilarity in life cycle stages of development across industries and within age categories. In addition, the model application is based on the assumption that performance develops constantly and linearly across age categories; however, actual SME performance tends to be stochastic.

The limitations lead to several recommendations for future research. It would be useful to test the life cycle-performance nexus using a time-series sample. In addition, examining various proxy variables of performance over several periods may lead to interesting findings. More and deeper empirical research into each life cycle stage for different industries could also be productive. Further attention could also be paid to explanations of the negative relationship between life cycle and firm performance in terms of growth and profitability, particularly to the somewhat contrasting finding of the present study that firm life cycle stage (firm age) and firm size affect performance in different ways, even though firm life cycle stage and firm size are positively related to each other. In addition, the present findings were obtained for just six industries, and the industry composition of the panel does not replicate the whole Swedish SME sector, nor the variety of SMEs in other countries. More attempts should therefore be made to investigate and compare various countries and industries. Future studies could investigate whether the relationships found here are linked to specific firm characteristics or to the Swedish context.

\section{References}

Adizes, I. (1989), Corporate Life Cycles: How and Why Corporations Grow and Die and What to Do About It, Prentice Hall, Englewood-Cliffs, NJ.

Aghion, P., Fally, T. and Scarpetta, S. (2007), "Credit constraints as a barrier to the entry and post-entry growth of firms”, Economic Policy, Vol. 22 No. 52, pp. 731-790.

Almeida, H. and Campello, M. (2007), "Financial constraints, asset tangibility, and corporate investment”, Review of Financial Studies, Vol. 20 No. 5, pp. 1429-1460.

Anthony, J. and Ramesh, K. (1992), “Association between accounting performance measures and stock prices: a test of the life cycle hypothesis", Journal of Accounting \& Economics, Vol. 15 Nos 2/3, pp. 203-227. 
Asimakopoulos, I., Samitas, A. and Papadogonas, T. (2009), "Firm-specific and economy wide determinants of firm profitability: Greek evidence using panel data”, Managerial Finance, Vol. 35 No. 11, pp. 930-939.

Barba Navaretti, G., Castellani, D. and Pieri, F. (2014), "Age and firm growth: evidence from three European countries", Small Business Economics, Vol. 43, pp. 9564-9566, DOI: 10.1108/204080012 11279265.

Beck, T., Demirguc-Kunt, A. and Maksimovic, V. (2005), "Financial and legal constraints to growth: does firm size matter?", Journal of Finance, Vol. 60 No. 1, pp. 137-177.

Berger, A. and Udell, G. (1998), "The economics of small business finance: the roles of private equity and debt markets in the financial growth cycle", Journal of Banking and Finance, Vol. 22 Nos 6/8, pp. 613-673.

Campa, J.M. and Kedia, S. (2002), "Explaining the diversification discount”, Journal of Finance, Vol. 57 No. 4, pp. 1731-1762.

Coad, A., Segarra, A. and Teruel, M. (2013), "Like milk or wine: does firm performance improve with age?”, Structural Change and Economic Dynamics, Vol. 24 No. 1, pp. 173-189.

Das, S. (1995), "Size, age and firm growth in an infant industry: the computer hardware industry in India", International Journal of Industrial Organization, Vol. 13 No. 1, pp. 111-126.

Dickinson, V. (2011), "Cash flow patterns as a proxy for firm life cycle”, The Accounting Review, Vol. 86 No. 6, pp. 1969-1994.

Dunlop, W. (1992), "Small vs. large firms in Australian manufacturing", Small Business Economics, Vol. 4 No. 1, pp. 45-58.

Evans, D.S. (1987), “The relationship between firm growth, size and age: estimates for 100 manufacturing industries", The Journal of Industrial Economics, Vol. 35 No. 4, pp. 567-581.

Fairfield, P., Sweeney, R. and Yohn, T. (1996), "Accounting classification and the predictive content of earnings", The Accounting Review, Vol. 71 No. 3, pp. 337-355.

Fama, E.F. and French, K.R. (2000), "Forecasting profitability and earnings", Journal of Business, Vol. 73 No. 1, pp. 161-175.

Fariñas, J.C. and Moreno, L. (2000), "Firms' growth, size and age: a nonparametric approach", Review of Industrial Organization, Vol. 17 No. 3, pp. 249-265.

Fitzsimmons, J.R., Steffens, P.R. and Douglas, E.J. (2005), "Growth and profitability in small and medium sized Australian firms", Proceedings AGSE Entrepreneurship Exchange, Melbourne, Victoria, pp. 164-178.

Galbraith, J.R. and Nathanson, D.A. (1979), "The role of organisational structure and process in strategy implementation", in Schendel, D.E. and Hofer, C.W. (Eds), Strategic Management: A New View of Business Policy and Planning, Little, Brown, Boston, MA, pp. 249-283.

Geroski, P. and Gugler, K. (2004), "Corporate growth and convergence in Europe", Oxford Economic Papers, Vol. 56 No. 4, pp. 597-620.

Goddard, J., Tavakoli, M. and Wilson, J. (2005), "Determinants of profitability in European manufacturing and services: evidence from a dynamic panel model", Applied Financial Economics, Vol. 15 No. 18, pp. 1269-1282.

Gschwandtner, A. (2005), "Profit persistence in the 'very' long run: evidence from survivors and exiters”, Applied Economics, Vol. 37 No. 7, pp. 793-806.

Hanks, S.H., Watson, C.J., Jansen, E. and Chandler, G.N. (1993), "Tightening the life-cycle construct: a taxonomic study of growth stage configurations in high-technology organizations", Entrepreneurship Theory and Practice, Vol. 2 No. 1, pp. 5-29.

\section{Life cycle and performance among SMEs}


$\mathrm{JRF}$ 15,5

570
Hart, P.E. (2000), “Theories of firms' growth and the generation of jobs”, Review of Industrial Organisation, Vol. 17 No. 3, pp. 229-248.

Hobdari, B., Derek, C.J. and Mygind, N. (2009), "Capital investment and determinants of financial constraints in Estonia”, Economic Systems, Vol. 33 No. 4, pp. 344-359.

James, C.M. and Wier, P. (1990), "Borrowing relationships, intermediation, and the cost of issuing public securities", Journal of Financial Economics, Vol. 28 No. 1, pp. 149-171.

Jovanovic, B. (1982), "Selection and evolution of industry", Econometrica, Vol. 50 No. 3, pp. 649-670.

Kazanjian, R.K. and Drazin, R. (1989), "An empirical test of stage of growth progression model”, Management Science, Vol. 35 No. 12, pp. 1489-1503.

Kirzner, I.M. (1997), "Entrepreneurial discovery and the competitive market process: an Austrian approach", Journal of Economic Literature, Vol. 35 No. 1, pp. 60-85.

Klepper, S. (1996), "Entry, exit, growth, and innovation over the product life cycle", American Economic Review, Vol. 86 No. 3, pp. 562-583.

Leonard-Barton, D. (1992), "Core capabilities and core rigidities: a paradox in managing new product development”, Strategic Management Journal, Vol. 13 No. 1, pp. 111-125.

Lester, D.L., Parnell, J.A. and Carraher, S. (2003), "Organization life cycle: a five-stage empirical scale", International Journal of Organizational Analysis, Vol. 11 No. 4, pp. 339-354.

Lester, D.L., Parnell, J.A., Crandall, W. and Menefee, M.L. (2006), "Organization life cycle and performance among SMEs: generic strategies for high and low performers", International Journal of Commerce and Management, Vol. 18 No. 4, pp. 313-330.

Levie, J.D. and Lichtenstein, B.B. (2010), "A terminal assessment of stages theory: introducing a dynamic states approach to entrepreneurship", Entrepreneurship Theory and Practice, Vol. 34 No. 2, pp. 317-350.

Lotti, F., Santarelli, E. and Vivarelli, M. (2009), "Defending Gibrat's law as a long-run regularity", Small Business Economics, Vol. 32 No. 1, pp. 31-44.

Maçãs Nunes, P., Viveiros, A. and Serrasqueiro, Z. (2012), "Are the determinants of young SME profitability different? Empirical evidence using dynamic estimators”, Journal of Business Economics and Management, Vol. 13 No. 3, pp. 443-470.

Maes, J., Sels, L. and Roodhoof, F. (2005), "Modelling the link between management practices and financial performance: evidence from small construction companies", Small Business Economics, Vol. 25 No. 1, pp. 17-34.

Majumdar and S.K. (1997), "The impact of size and age on firm-level performance: some evidence from India”, Review of Industrial Organization, Vol. 12 No. 2, pp. 231-241.

Mead, D.C. and Liedholm, C. (1998), "The dynamics of micro and small enterprises in developing countries", World Development, Vol. 26 No. 1, pp. 61-74.

Nissim, D. and Penman, S. (2001), "Ratio analysis and equity valuation: from research to practice", Review of Accounting Studies, Vol. 6 No. 1, pp. 109-154.

O'Farrell, P.N. and Hitchens, D. (1988), "Alternative theories of small firm growth: a critical review”, Environment and Planning A, Vol. 20 No. 2, pp. 1365-1383.

Oliveira, B. and Fortunato, A. (2006), "Firm growth and liquidity constraints: a dynamic analysis", Small Business Economics, Vol. 27 No. 1, pp. 139-156.

Quinn, R.E. and Cameron, K. (1983), "Organizational life cycles and shifting criteria of effectiveness: some preliminary evidence”, Management Science, Vol. 29 No. 1, pp. 33-51.

Rajan, R. and Zingales, L. (1995), "What do we know about capital structure? Some evidence from international data”, Journal of Finance, Vol. 50 No. 5, pp. 1421-1460. 
Reichstein, T., Dahl, M.S., Ebersberger, B. and Jensen, M.B. (2010), “The devil dwells in the tails: a quantile regression approach to firm growth", Journal of Evolutionary Economics, Vol. 20 No. 2, pp. 219-231.

Scott, M. and Bruce, R. (1987), "Five stages of growth in small business", Long Range Planning, Vol. 20 No. 3, pp. 45-52.

Serrasquiero, Z., Maçãs Nunes, P., Leitão, J. and Armada, M. (2010), “Are there non-linearities between SME growth and its deteminants? A quantile approach”, Industrial and Corporate Change, Vol. 19 No. 4, pp. 1071-1108.

Shanmugam, K. and Bhaduri, S. (2002), "Size, age and firm growth in the Indian manufacturing sector”, Applied Economics Letters, Vol. 9 No. 9, pp. 607-613.

Sorensen, J.B. and Stuart, T.E. (2000), "Aging, obsolescence, and organizational innovation", Administrative Science Quarterly, Vol. 45 No. 1, pp. 81-112.

Statistics Sweden (2011), "Definition of SMEs", available at: www.scb.se/ (accessed 10 March 2014).

Stierwald, A. (2010), "The causes of profit heterogeneity in large Australian firms", Working Paper No. 7/10, Melbourne Institute of Applied Economic and Social Research, University of Melbourne, Melbourne, Victoria.

Storey, D.J. (1994), Understanding the Small Business Sector, Routledge, New York, NY.

Tam, S., Lee, W.B. and Chung, W. (2001), "Growth of a small manufacturing enterprise and critical

factors for success”, International Journal of Manufacturing Technology and Management, Vol. 3 Nos 4/5, pp. 444-454.

Yasuda, T. (2005), "Firm growth, size, age and behavior in Japanese manufacturing", Small Business Economics, Vol. 24 No. 1, pp. 1-15.

Zellner, A. and Theil, H. (1962), "Three-stage least squares: simultaneous estimation of simultaneous equations", Econometrica, Vol. 30 No. 1, pp. 54-78.

\section{About the authors}

Darush Yazdanfar is Associate Professor $(\mathrm{PhD})$ of Corporate Finance and Risk Management at Mid Sweden University. His research interests are corporate finance, the stock market, risk management, and entrepreneurial finance.

Peter Öhman is Associate Professor ( $\mathrm{PhD})$ of Accounting at Mid Sweden University. His research interests are accounting, auditing and banking. Peter Öhman is a corresponding author and can be contacted at: Peter.Ohman@miun.se

\section{Life cycle and performance among SMEs}

To purchase reprints of this article please e-mail: reprints@emeraldinsight.com Or visit our web site for further details: www.emeraldinsight.com/reprints 